\title{
PKM- Pengabdian Kepada Masyarakat : Kaligrafi Sabut Kelapa
}

\author{
Pristi Suhendro Lukitoyo ${ }^{1 *}$, Elvida Liani Nasution ${ }^{2}$, Indah Sarini ${ }^{3}$, Pratama Imanda Putra ${ }^{4}$ \\ 1,2,3 Program Studi Pendidikan Sejarah, Fakultas Ilmu Sosial, Universitas Negeri Medan \\ 4 Program Studi Pendidikan Geografi, Fakultas Ilmu Sosial, Universitas Negeri Medan
}

\author{
A R T I C L E I N F O \\ Article history: \\ Received 20 February 2019 \\ Received in revised form \\ 10 March 2019 \\ Accepted 30 April 2019 \\ Available online 27 May \\ 2019 \\ Kata Kunci: \\ Kaligrafi, Sabut Kelapa \\ Masyarakat \\ Keywords: \\ Calligraphy, Coconut Fiber, \\ Society
}

\begin{abstract}
A B S T R A K
Kegiatan PKM-M ini bertujuan untuk meningkatkan penghasilan masyarakat khususnya Ibu-ibu rumah tangga yang ada di Desa Suka Maju, Kecamatan Tanjung Pura, Kabupaten Langkat. Adapun program yang dilakukan ialah pelatihan pembuatan kaligrafi dari limbah sabut kelapa. Desa Suka Maju memiliki banyak sekali tanaman pohon kelapa milik masyarakat sekitar. Selama ini masyarakat di Desa tersebut belum memiliki pemahaman mengenai pemanfaatan limbah sabut kelapa yang notabene bisa dijadikan sebuah barang yang memiliki nilai jual. Pelaksanaan kegiatan ini dilakukan dengan metode teknik penyuluhan dan pelatihan. Teknik penyuluhan dalam kegiatan ini merupakan kegiatan sosialisasi kepada masyarakat tentang pemanfaatan sabut kelapa sebagai barang yang memiliki nilai jual. Dengan demikian masyarakat memiliki pemahaman tentang pemanfaatan dan pendayagunaan limbah tersebut. Setelah melakukan penyuluhan selanjutnya dilakukankegiatan pelatihan. Kegiatan pelatihan ini bertujuan untuk melatih keterampilan ibu-ibu rumah tangga dalam membuat kaligrafi dari sabut kelapa. Pelatihan ini diajarkan dari tahap awal hingga akhir sehingga mereka memiliki kemampuan yang matang dalam membuat produk tersebut. Hasil dari kegiatan ini ialah Masyarakat memiliki kemampuan untuk membuat produk dari bahan limbah secara mandiri, Membuka lapangan pekerjaan baru untuk masyarakat terutama ibu-ibu rumah tangga, dan Menambah penghasilan masyarakat dari hasil penjualan produk kaligrafi sabut kelapa.
\end{abstract}

\section{A B S T R A C T}

This PKM-M activity aims to increase the income of the community especially the housewives in advanced villages, Tanjung Pura sub-district, Langkat district. The program carried out is a training in making calligraphy from coconut fiber waste. The village likes to go forward with lots of coconut trees belonging to the surrounding community. So far, the community in the village does not yet have an understanding of the use of coconut husk waste which incidentally can be used as an item that has selling value. The implementation of this activity is carried out by extension and training techniques. The counseling technique in this activity is a socialization activity to the community about the use of coconut fiber as an item that has selling value. Thus the community has an understanding of the utilization and utilization of these wastes. After conducting counseling, further training activities were carried out. This training activity aims to train the skills of housewives in making calligraphy from coconut fiber. This training is taught from the beginning to the end so that they have the mature ability to make the product. The results of this activity are that the community has the ability to make products from waste materials into products that have selling value, open new jobs for the community, especially housewives, and increase the income of the community from the sale of coconut fiber calligraphy products.

Copyright (C) Universitas Pendidikan Ganesha. All rights reserved.

\footnotetext{
* Corresponding author.

E-mail addresses: elvidalianinst0627@gmail.com (Pristi Suhendro Lukitoyo)
} 


\section{Pendahuluan}

Kelurahan Produksi buah kelapa Indonesia rata-rata 15,5 miliyar butir/tahun atau setara dengan 3,02 juta ton kopra, 375 juta ton air, 0,75 juta ton arang tempurung, 1,8 juta ton serat sabut, dan 3,3 juta ton debus abut (Agustian et al., 2003: Allorerung dan Lay, 1998:Antonim, 2000; Nur et al., 2003; apcc. 2003). Industry pengolahan buah kelapa umumnya masih terfokus kepada pengolahan hasil daging buah sebagai hasil utama, sedangkan industry yang mengolah hasil samping buah (by-product) seperti air, sabut, dan tempurung kelapa masih tradisional dan berskala kecil, padahal potensi ketersediaan bahan baku untuk membangun pongolahannya masih sangat besar. Kelapa (Cocos nucifera) merupakan salah satu anggota tanaman palma yang paling dikenal dan bnayak tersebar di daerah tropis. Pohon kelapa meruapakan jenis tanaman yang berumah satu dengan batang tanaman tumbuh lurus keatas dan tidak bercabang. Tinggi pohon kelapa dapat mencapai 3-4 meter lebih dari sirip-sirip lidi yang menompang tiap helaian.

Masyarakat Desa Suka Maju adalah masyarakat agraris yaitu masyarakat yang sebagian besar menyandarkan penghasilannya pada bidang pertanian. Laki-laki dan perempuan di desa ini dapat dikatakan semuanya bekerja sebagai petani. Selain pertanian, untuk menunjang pendapatan masyarakat di desa ini, sebagian diantara mereka ada yang berkebun seperti menanami lahan yang ada dengan tanaman kelapa dan kelapa sawit. Masyarakat menganggap dengan memiliki kebun yang luas maka bisa menunjang penghasilan untuk memenuhi kebutuhan hidupnya. Oleh karena itu sangat banyak ditemukan tanaman pohon kelapa milik masyarakat sekitar di desa tersebut.

Mata pencaharian masyarakat sebagian besar adalah bertani. Namun kegiatan bertani memiliki priode dimana dalam setahun hanya bisa dilakukan dua kali tanam padi. Ibu-ibu rumah tangga di desa ini pun banyak yang menganggur, sebagian besar yang bekerja adalah para suami saja. Jika pun ada yang bekerja itupun hanya sebagai buruh upah di sawah milik orang. Pekerjaan buruh upah di sawah orang hanya dilakukan pada musim awal penanaman tanaman padi setelah itu perempuan-perempuan di desa banyak yang menganggur dan menghabiskan waktu di rumah tanpa ada kegiatan yang bermanfaat.

Mata pencaharian sebagai petani padi dirasa kurang memenuhi kebutuhan masyarakat di desa itu. Hal itu dikarenakan proses perawatan untuk tanaman padi membutuhkan biaya yang banyak sehingga pendapatan yang diterima dari hasil panen pun terkadang habis untuk biaya perawatan saja. oleh karena itu sebagian dari mereka menyandarkan hidupnya dari hasil kebun tanaman kelapa yang mereka miliki. Banyaknya tanaman kelapa di desa ini juga menyebabkan limbah sabut kelapa berserakan tanpa ada pengelolaan yang baik. Keinginan masyarakat mengolah limbah tersebut tidak dapat terealisasikan sebab tidak adanya pemahaman dan keterampilan mereka untuk mengolah limbah tersebut menjadi barangbarang yang bernilai jual.

Berangkat dari permasalahan tersebut Tim PKM-M Universitas Negeri Medan melihat ada hal-hal yang bisa dimanfaatkan dari limbah-limbah perkebunan kelapa milik masyarakat sekitar. Sebagaimana yang diketahui bahwa pohon kelapa adalah tanaman yang sangat banyak daya gunanya, mulai dari buahnya, pohon, pelepah, dan bahkan sabut nya oleh karena itulah sebagian orang menyebutnya sebagai pohon kehidupan. Sabut kelapa adalah benda yang yang dianggap oleh sebagian orang sebagai limbah ataupun barang yang tidak memiliki manfaat. Namun, hal itu adalah mindset yang keliru. Dikarenakan sabut kelapa dapat dimanfaatkan sebagai benda yang mempunyai nilai ketika dapat diolah menjadi benda yang unik dan bernilai jual. Banyak kerajinan yang dapat dihasilkan dari olahan sabut kelapa misalnya keset, Sapu, Tas, Sandaran kursi, Kasur dan lain sebagainya. Semuanya dapat dihasilkan dari olahan sabut kelapa. Namun, dalam hal ini tim PKM menekankan bahwasannya sabut kelapa ini akan diolah mejadi produk kaligrafi yang unik dan cantik.

Kaligrafi merupakan tulisan indah, dalam hal ini kaligrafi yang dimaksudkan adalah kaligrafi ayat Al-Quran, yang ditulis atau dibuat secara indah. Dibuat seindah mungkin, baik bentuk maupun warnanya, tetapi tidak menghilangkan kaidah-kaidah tulis apalagi merubah bacaan dan artinya. Kaligrafi dibuat untuk menyalin ayat-ayat Al-Quran atau hadist, yang sekaligus untuk memperindah tempat-tempat tertentu, baik di dinding atau bagian lain dari suatu bangunan, maupun pada media khusus seperti kertas atau kanvas dan papan atau triplex.

Kaligrafi Arab yang bersumber pada Al-Qur'an selain memiliki bentuk yang artistik juga memiliki makna yang luhur yang merupakan penggambaran firman Allah. Kaligrafi Arab sebagai suatu karya seni merupakan paduan antara ayat yang dikutip dalam Al-Qur 'an dengan bentuk visual yang ditampilkan sehingga menjadi suatu karya seni yang dibalik keindahan visual (makna yang tersurat) juga mengandung makna non visual (makna yang tersirat). Makna adalah ujung tombak dalam ekspresi seni, dan bentuk visual yang dihadirkannya adalah salinan atau representasi yang tak pernah sempurna dan lengkap (Abdul Hadi HW, 2000:336). Karya-karya yang diperoleh melalui inspirasi yang hidup dan pengetahuan 
yang mendalam, serta kreativitas dan penguasaan teknik yang tinggi akan sendirinya merupakan karya yang inspiratif dan dapat memberi makna kepada penikmatnya (Rispul ,2012).

Kaligrafi atau khath merupakan salahsatu cabang seni Islam yang banyak menarik untuk dibicarakan. Salah satu daya tarik yang banyak mendapat perhatian para penulis sejarah dan kebudayaan adalah tentang dinamika pertumbuhannya yang heroik melebihi mazhab-mazhab tulisan lain di dunia. Dalam artikel "International Islamic Calligraphy Competition" dinyatakan bahwa kaligrafi Islam sering disebut "seninya seni Islam" (the art of Islamic art), 2 menunjukkan bahwa kaligrafi mempunyai makna yang luhur, dan kedudukannya dalam kesatuan ruang dan waktu bagi kebudayaan Islam tidak diragukan lagi. Selama lebih 14 abad kaligrafi memainkan peran dominan yang mengisi hiruk pikuk perjalanan seni Islam secara menyeluruh. Pertumbuhan kaligrafi yang pesat dan penerimaannya yang final dari kaum muslimin tidak lepas dari pengaruh Al-Qur'an yang sejak diturunkannya berbicara tentang perintah membaca dan menulis (QS Al-'Alaq/96: 1-5) dan ayatayat lain tentang tulisan dengan perangkatperangkatnya yang jadi motivator penggerak pertumbuhannya yang pesat.3 Gambaran yang jelas tentang lambatnya pertumbuhan kaligrafi Arab sebelum diturunkannya Al-Qur'an, terlihat dari hanya adanya dua gaya kuno aksara Arab yaitu Musnad dan Nabati (selama sekitar 1.500 tahun sejak periode Hiroglip hingga masa kedatangan Islam). Masyarakat Arab sebelum Islam dikenal nomaden yang tidak memungkinkan hidup tumbuh dan berkembang bersama perkembangan kegiatan baca tulis, dan umumnya mereka mengenal tulisan dan bacaan hanya beberapa saat menjelang kedatangan Islam (Sirojuddin ,2014).

Sabut kelapa yang merupakan limbah saat panen buah kelapa selama ini hanya dimanfaatkan oleh pelaku kerajinan, namun belum digunakan untuk bahan stabilisasi tanah (Sriyati Ramadhani, 2011). Beberapa keistimewaan pemanfaatan serat serabut kelapa sebagai stabilisator dalam upaya perbaikan tanah yang ramah lingkungan dan mendukung gagasan pemanfaatan serat serabut kelapa menjadi salah satu bahan tambah usaha stabilitas terhadap tanah lempung (Sazuatmo,2011).

Serabut kelapa juga mempunyai keuntungan yaitu tahan terhadap serangan mikroorganisme, pelapukan dan pekerjaan mekanis (gosokan dan pukulan). Serat serabut kelapa juga mempunyai sifat yang ulet, dapat menyerap air, dan mempunyai tingkat keawetan yang baik jika tidak berhubungan langsung dengan cuaca (Mulyono, 2004).

Sabut kelapa merupakan bagian terluar buah kelapa yang membungkus tempurung kelapa. Ketebalan sabut kelapa berkisar 5-6 cm yang terdiri atas lapisan terluar (exocarpium) dan lapisan dalam (endocarpium). Endocarpium mengandung serat-serat halus yang dapat digunakan sebagai bahan pembuat tali, karung, pulp, karpet, sikat, keset, isolator panas dan suara, filter, bahan pengisi jok kursi/mobil dan papan hardboard. Satu butir buah kelapa menghasilkan 0,4 kg sabut yang mengandung $30 \%$ serat. Komposisi kimia sabut kelapa terdiri atas selulosa, lignin, pyroligneous acid, gas, arang, ter, tannin, dan potasium (Rindengan, et al., 1995). India dan Sri Lanka adalah produsen terbesar produkproduk dari sabut dengan volume ekspor tahun 2000 masing-masing 55.352 ton dan 127.296 ton dan masing-masing terdiri atas 6 dan 7 macam produk. Pada saat yang sama, Indonesia hanya mengekspor satu jenis produk (berupa serat mentah) dengan volume 102 ton. Angka ini menurun tajam dibandingkan ekspor tertinggi pada tahun 1996 yang mencapai 866 ton (Ditjenbun, 2002; BPS, 2002) (Indahyani ,2011).

Kelapa (Cocos nucifera) adalah anggota tunggal dalam marga Cocos dari suku aren-arenan atau Arecaceae. Tumbuhan ini dimanfaatkan hampir semua bagiannya oleh manusia sehingga dianggap sebagai tumbuhan serbaguna, terutama bagi masyarakat pesisir. Kelapa juga adalah sebutan untuk buah yang dihasilkan tumbuhan ini. Semua bagian pada pohon kelapa memiliki fungsi yang bermanfaat untuk kehidupan. Dari bagian daun, bunga, buah, batang, dan bagian akar dapat memberikan manfaat baik bagi lingkungannya juga dapat bermanfaat untuk manusia. (Cocopreneurship, Sarmidi Amin). Bagian-bagian buah kelapa diantaranya kulit luar, sabut kelapa, tempurung, kulit daging buah, daging buah, dan air kelapa. [1][2] Sabut merupakan bagian mesokarp (selimut) yang berupa serat-serat kasar kelapa. Bagian yang berserabut ini merupakan kulit dari buah kelapa dan dapat dijadikan sebagai bahan baku aneka industri. Serat adalah bagian yang berharga dari sabut. Dilihat sifat fisisnya sabut kelapa terdiri dari serat kasar dan halus, mutu serat ditentukan oleh warna, mengandung unsur kayu. Produk yang sudah dihasilkan dari bagian buah kelapa yang berserabut ini seperti karpet, keset, sikat, bahan pengisi jok mobil, tali dan lainnya. Dari sabut dapat diperoleh serat matras, serat berbulu, serta sekam atau dedak atau gabus. Serat matras tersebut digunakan untuk sikat pembersih, sapu, keset sedangkan sekam atau gabus digunakan sebagai media tanam dan pupuk kalium. Selain itu karena serat yang mempunyai karakteristik yang khas menjadikan sabut kelapa banyak dijadikan sebagai kerajinan (Shofiyah, 2015).

Banyak manfaat dari pohon kelapa, maka dari itu pohon kelapa sering disebut pohon 1000 (seribu) manfaat. Karena dari ujung akar pohon kelapa, sampai denga ujung daun pohon kelapa bisa dimanfaatkan dengan bebagai macam bentuk dan macam-macam kegunaan. Kelapa adalah pohon serba guna bagi masyarakat tropika. Hampir semua bagiannya dapat dimanfaatkan orang. Akar kelapa menginspirasi 
penemuan teknologi penyangga bangunan Cakar Ayam (dipakai misalnya pada Bandar Udara Soekarno Hatta) oleh Sedijatmo. Kayu dari batangnya, yang disebut kayu glugu, dipakai orang sebagai kayu dengan mutu menengah, dan dapat dipakai sebagai papan untuk rumah. Daunnya dipakai sebagai atap rumah setelah dikeringkan. Daun muda kelapa, disebut janur, dipakai sebagai bahan anyaman dalam pembuatan ketupat atau berbagai bentuk hiasan yang sangat menarik, terutama oleh masyarakat Jawa dan Bali dalam berbagai upacara, dan menjadi bentuk kerajinan tangan yang berdiri sendiri (seni merangkai janur). Tangkai anak daun yang sudah dikeringkan, disebut lidi, dihimpun menjadi satu menjadi sapu (Arifiandi ,2015.

Beberapa keistimewaan pemanfaatan serat sabut kelapa sebagai bahan baru rekayasa antara lain menghasilkan bahan baru komposit alam yang ramah lingkungan dan mendukung gagasan pemanfaatan serat sabut kelapa menjadi produk yang memiliki nilai ekonomi dan teknologi tinggi. Untuk mencapai tujuan tersebut maka perlu dilakukan adanya penelitian tentang pemanfaatan limbah serat sabut kelapa sebagai bahan pembuat helm pengendara kendaraan roda dua (Amin ,2010).

Sabut kelapa adalah bagian penting dari buah kelapa dengan porsi $35 \%$ dari seluruh berat buah kelapa. Serat sabut kelapa memiliki kandungan selulose cukup tinggi sehingga serat tersebut dapat digunakan sebagai bahan pembuatan pulp, yang selanjutnya dapat dimanfaatkan dalam pembuatan bahan kertas komposit yang terdiri dari campuran pulp serat sabut kelapa dan pulp pembentuk HVS. Penelitian ini bertujuan untuk mempelajari pengaruh waktu hidrolisis dan konsentrasi $\mathrm{NaOH}$ terhadap kadar alfa seluluse, dan mempelajari karakteristik kertas komposit (Arini ,2010).

Keuntungan dari penggunaan sabut kelapa yaitu sabut kelapa memiliki sifat tahan lama, sangat ulet, kuat terhadap gesekan, tidak mudah patah, tahan terhadap air, tidak mudah membusuk, tahan terhadap jamur, dan hama serta tidak dihuni oleh rayap dan tikus. Sabut kelapa terdiri dari serat dan gabus yang menghubungkan satu serat dengan serat lainnya yang merupakan bagian berharga dari sabut. Setiap butir kelapa rata-rata mengandung serat 525 gram (75\% dari sabut), dan gabus 175 gram (25\% dari sabut). Maka dari itu sangat banyak keuntungan jika menggunakan sabut kelapa sebagai bahan utama dalam pembuatan kaligrafi.

\section{Metode}

Metode yang dilakukan antara lain penyuluhan, persiapan dan pelatihan pembuatan kaligrafi sabut kelapa. Persiapan dan pelatihan yang dilakukan mahasiswa meliputi pemberian materi tentang pemanfaatan sabut kelapa, pelatihan pembuatan produk dan pemasaran produk.

Pada tahap penyuluhan, Tim PKM-M memberikan sosialisasi kepada masyarakat sekitar tentang pemanfaatan dan gambaran pengelolaan sabut kelapa menjadi produk "kaligrafi sabut kelapa" sehingga memberikan pemahaman awal bagi masyarakat tentang program yang akan dilakukan. Setelah penyuluhan dilakukan maka tahap selanjutnya ialah pelatihan pembuatan kaligrafi sabut kelapa dengan masyarakat sekitar. Tahap pelatihan dimulai dari tahap persiapan alat dan bahan, penggilingan sabut kelapa, dan tahap pembuatan kaligrafi. Produk kaligrafi yang telah dihasilkan oleh masyarakat selanjutnya akan di pasarkan. Proses pemasaran dilakukan melalui penjualan secara online maupun penjualan secara langsung. Dengan adanya kegiatan ini maka secara langsung dapat membuka lapangan pekerjaan baru di desa tersebut, menumbuhkan jiwa keterampilan ibu-ibu rumah tangga serta menambah pendapatan bagi masyarakat di desa tersebut.

\section{Hasil dan pembahasan}

Berdasarkan Pelaksanaan pelatihan dalam pembuatan kaligrafi sabut kelapa ini untuk meningkatkan pendapatan ekonomi masyarakat Desa Suka Maju, Kecamatan Tnajung Pura. Kabupaten Langkat. Pada awalnya tim PKM melakukan penyuluhan serta pelatihan-pelatihan kepada masyarakat terutama ibu-ibu rumah tangga dan memfasilitasi masyarakat dengan bahan-bahan yang telah di persiapkan sebelumnya oleh tim PKM.

Kegiatan pertama yakni melakukan survey ke lapangan yang menjadi tempat pengabdian yakni di Desa Suka Maju Kecamatan Tanjung Pura, Kabupaten Langkat. Kegiatan survey ini mencakup pengenalan dengan masyarakat sasaran, melakukan kerjasama dengan mitra serta melihat potensi alam Desa Suka Maju yang dapat menunjang program pengabdian ini. Kegiatan kedua yakni memberikan pelatihan yang diawali dengan pemberian materi tentang pemanfaatan sabut kelapa sebagai barang yang bernilai jual serta memberikan gambaran tentang desain kaligrafi sabut kelapa yang akan dibuat. Kegiatan ketiga yakni pengumpulan limbah sabut kelapa dari kebun-kebun milik masyarakat sekitar. Setelah kegiatan pengumpulan sabut kelapa tersebut maka tahap selanjutnya ialah menggilingnya dengan mesin sehingga menghasilkan barang dasar yakni serabut kelapa yang halus dan sudah dibersihkan. 
Tahapan selanjutnya ialah melakukan pengeringan dengan menjemur sabut kelapa tersebut selama satu hari. Kegiatan ke empat yaitu tim PKM mempersiapkan alat dan bahan serta melakukan pelatihan pembuatan kaligrafi sabut kelapa kepada masyarakat sekitar, kegiatan ini diikuti oleh ibu-ibu rumah tangga yang berjumlah sekitar 12 orang. Kegiatan ini dilakukan pada pukul 14.00-17.00 WIB. Dalam kegiatan pelatihan pertama, ibu-ibu menghasilkan 2 buah kaligrafi sabut kelapa. Kegiatan kelima yakni melakukan pelatihan kembali kepada ibu-ibu rumah tangga, dimana hal ini bertujuan untuk memantapkan keahlian mereka dalam membuat produk tersebut. Dari pelatihan ini tim bersama masyarakat menghasilkan 2 buah kaligrafi. Kegiatan keenam yaitu memberikan pelatihan dengan menyerahkan sepenuhnya proses pengerjaan kepada ibu-ibu rumah tangga. Hal ini bertujuan untuk melihat sejauh mana kemampuan mereka untuk membuat kaligrafi dari sabut kelapa tersebut.

Seperti kegiatan-kegiatan sebelumnya tahapan awal dimulai pekerjaan pada pukul 14.00-17.00 WIB dan menghasilkan 2 buah kaligrafi sabut kelapa. sehingga, dari beberapa pertemuan dan pelatihan yang telah terlaksana kepada masyarakat tim PKM dapat menghasilkan sebanyak 6 buah kaligrafi. Berikut ini merupakan rincian kegiatan pelaksanaan yang dilakukan dapat dilihat pada Tabel berikut ini.

Tabel 1. Rincian Pelaksanaan Kegiatan

\begin{tabular}{|c|c|c|}
\hline No. & Waktu dan Program & Implementasi \\
\hline 1. & Survey. Sabtu, 30 Maret 2019 & $\begin{array}{l}\text { Pengenalan dengan masyarakat sasasaran, melakukan } \\
\text { kerjasama dengan mitra serta melihat potensi alam Desa } \\
\text { Suka Maju yang dapat menunjang program pengabdian ini. }\end{array}$ \\
\hline 2. & $\begin{array}{l}\text { Pemberian materi tentang } \\
\text { pemanfaatan sabut kelapa, Sabtu, } \\
6 \text { April } 2019\end{array}$ & $\begin{array}{l}\text { pemberian materi tentang pemanfaatan sabut kelapa } \\
\text { sebagai barang yang bernilai jual serta memberikan } \\
\text { gambaran tentang desain kaligrafi sabut kelapa yang akan } \\
\text { dibuat. }\end{array}$ \\
\hline 3. & $\begin{array}{l}\text { Persiapan alat dan bahan } \\
\text { Minggu, } 7 \text { April } 2019\end{array}$ & $\begin{array}{l}\text { Pengumpulan limbah sabut kelapa dari kebun-kebun milik } \\
\text { masyarakat sekitar serta penggilingannya sehingga dapat } \\
\text { dijadikan bahan dasar pembuatan produk. }\end{array}$ \\
\hline 4. & Pelatihan I. Sabtu, 13 April 2019 & $\begin{array}{l}\text { melakukan pelatihan pembuatan kaligrafi sabut kelapa } \\
\text { kepada masyarakat sekitar, kegiatan ini diikuti oleh ibu-ibu } \\
\text { rumah tangga yang berjumlah sekitar } 12 \text { orang. Dari } \\
\text { kegiatan ini Tim PKM dan ibu-ibu rumah tangga } \\
\text { menghasilkan } 2 \text { buah produk kaligrafi. }\end{array}$ \\
\hline
\end{tabular}

5. Pelatihan II. Sabtu, 20 April 2019 Pelatihan kembali kepada ibu-ibu rumah tangga, dimana hal ini bertujuan untuk memantapkan keahlian mereka dalam membuat produk tersebut. Dari pelatihan kedua ini kami menghasilkan 2 buah produk kaligrafi.

6. Pelatihan III. Sabtu, 4 Mei 2019 Memberikan pelatihan dengan menyerahkan sepenuhnya proses pengerjaan kepada ibu-ibu rumah tangga. Hal ini bertujuan untuk melihat sejauh mana kemampuan mereka untuk membuat kaligrafi dari sabut kelapa tersebut. Dari pelatihan ketiga ini kami menghasilkan 2 buah produk kaligrafi.

\begin{tabular}{lll}
\hline 7 & Pelatihan IV. Sabtu, 11 Mei 2019 & $\begin{array}{l}\text { Memantabkan hasil dari pelatihan dalam pembuatan } \\
\text { kaligrafi sabut kelapa }\end{array}$ \\
\hline 8 & Pelatihan V, Sabtu, 25 Mei 2019 & Pelatihan pembuatan kaligrafi sabut kelapa \\
\hline 9 & Pelatihan VI, Minggu 26 Mei 2019 & $\begin{array}{l}\text { Memantau ibu-ibu dalam pembuatan kaligrafi sabut kelapa } \\
\text { secara mandiri }\end{array}$ \\
\hline 10 & Pelatihan VII, Senin 27 Mei 2019 & $\begin{array}{l}\text { Pelatihan akhir kepada ibu-ibu dalam pembuatan kaligrafi } \\
\text { sabut kelapa. }\end{array}$ \\
\hline
\end{tabular}




\begin{tabular}{lll}
\hline $11 \quad$ Evaluasi., 01 Juni 2019 & Pengujian kepada masyarakat yang sudah mengikuti \\
& latihan disertai melihat bagaimana kebermanfaatan \\
& kelebihan dan kekurangan yang telah dilakukan selama \\
& program ini berlangsung. \\
\hline
\end{tabular}

Setelah tindakan dilakukan sebanyak 11 kali terhadap 12 ibu-ibu rumah tangga, hasil penelitian menunjukkan adanya peningkatan dari pelatihan yang dilakukan dalam pembuatan kaligrafi sabut kelapa.

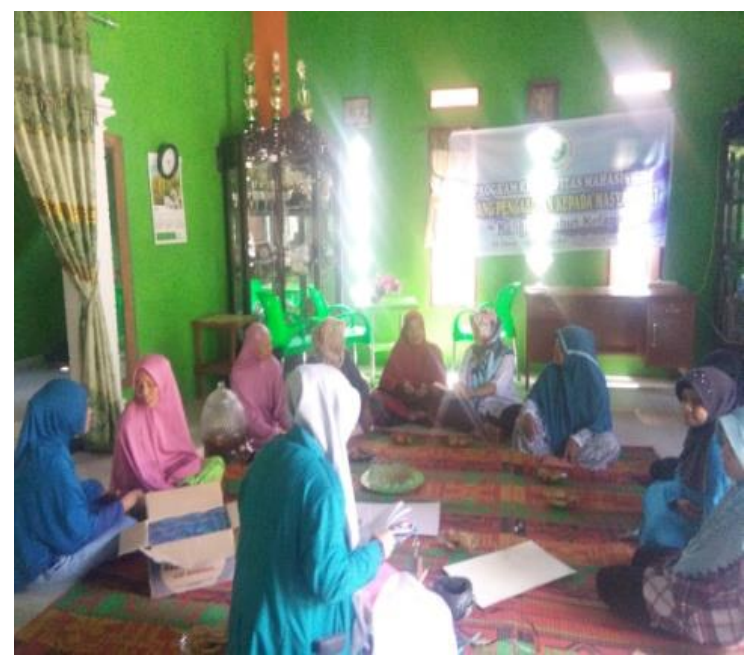

Gambar 1. Kegiatan Penyuluhan

Teknik penyuluhan dilakukan dengan metode ceramah dan pelatihan. Teknik ini dilakukan untuk memudahkan pemberian pemahaman kepada masyarakat tentang pemanfaatan limbah sabut kelapa menjadi produk yang bernilai jual yakni kaligrafi. Dalam penyampaian materi warga juga diberikan video tutorial pembuatan kaligrafi sabut kelapa sehingga mempermudah transfer ilmu pengetahuan yang akan diterapkan.

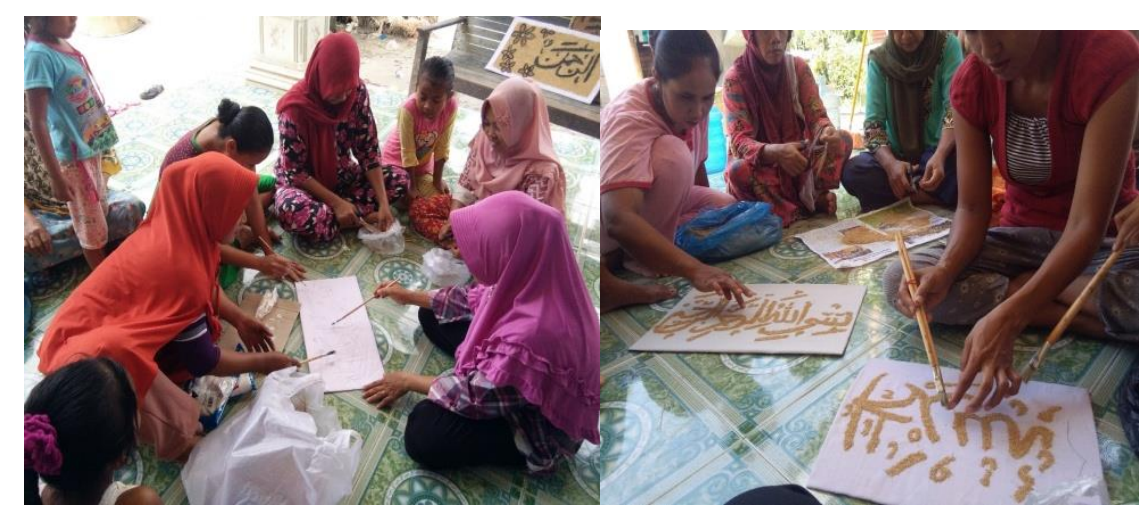

Gambar 2. Kegiatan Pelatihan

Pelatihan merupakan proses implementasi dari materi yang telah diberikan dalam kegiatan penyuluhan. Pelatihan dilakukan kepada ibu-ibu rumah tangga terkait dengan cara pembuatan kaligrafi sabut kelapa. Selain itu pelatihan juga berfungsi untuk meningkatkan kemampuan ibu-ibu rumah tangga dalam membuat produk tersebut sehingga mereka bisa mandiri dalam pembuatan kaligrafi sabut kelapa selanjutnya. Kegiatan pelatihan dan pendampingan dilakukan setiap 1 minggu sekali terhadap ibu-ibu rumah tangga. Dari setiap pelatihan yang dimulai dari pukul 14.00-17.00 WIB Tim bersama kelompok ibu rumah tangga menghasilkan dua produk kaligrafi. Sehingga dari beberapa pertemuan yang telah dilakukan dapatmenghasilkan 6 buah produk kaligrafi sabut kelapa. 


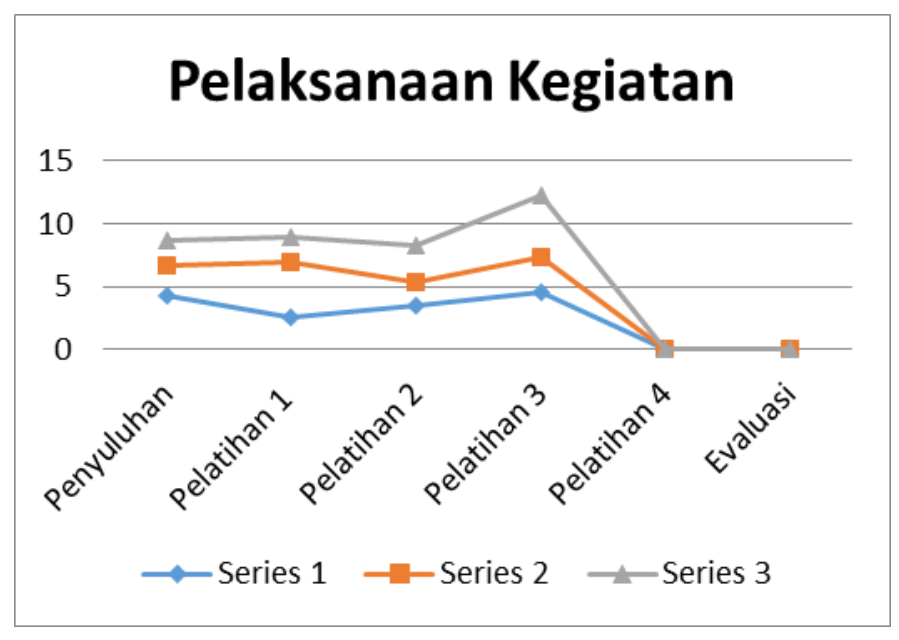

Gambar 3. Hasil Tes

Pada bagian terakhir, tim dan para pelatih PKM terus memantau kegiatan perkembangan kaligrafi sabut kelapa ini. Setelah ada melihat kekurangan dari kegiatan yang telah dilaksanakan, Tim PKM memberikan pelatihan secara insentif, agar Ibu-ibu rumah tangga ini lebih kreatif dan mahir dalam mengembangkan kegiatan pembuatan kaligrafi sabut kelapa secara efisien.

\section{Simpulan dan saran}

Pengabdian kepada masyarakat dalam hal ini adalah Pelatihan Pembuatan Kaligrafi dari Limbah sabut kelapa di Desa Suka Maju, Kecamatan Tanjung Pura. Kabupaten Langkat sudah terlaksana sesuai rencana sesuai rencana, mulai dari bulan Maret sampai Bulan Juni 2019. Secara umum kegiatan berjalan sesuai dengan yang telah direncanakan. Dari bahan limbah sabut kelapa berhasil digunakan untuk pembuatan kaligrafi, dibuat dengan baik oleh ibu-ibu rumah tangga. Pelatihan pembuatan kaligrafi dari bahan limbah sabut kelapa yang telah dibuat kaligrafi pada media papan atau triplex dan kain putih. Guna terwujudnya hasil yang maksimal tentu ada follow up dari kegiatan pelatihan ini, karena keberhasilan sebuah kegiatan pelatihan ini adalah adanya kesadaran dan keinginan dari ibu-ibu rumah tangga untuk mengaplikasikan serta mengembangkannya.

\section{Daftar Rujukan}

Arini ,Yessica (2010). Pemanfaatan Sabut Kelapa Sebagai Bahan Baku Pembuatan Kertas Komposit Alternatif . Jurnal Widya Teknik Vol. 9, No. 1, 2010

Arifiandi, Yosha (2015). Penyuluhan Dan Pelatihan Pengolahan Sabut Kelapa . Jurnal Inovasi dan Kewirausahaan Volume 4 No. 2, Mei 2015

Allorerung, D., dan A. Lay, 1998. Kemungkinan Pengembnagan pengolahan sabut kelapa secara terpadu skala pedesaan. Prosiding Konperensi Nasional Kelapa IV. Bandar Lampung 21-23 April 1998 Pp.327 -340 .

Amin ,Muh (2010). Pemanfaatan Limbah Serat Sabut Kelapa Sebagai Bahan Pembuat Helm Pengendara Kendaraan Roda Dua . Jurnal.unimus.ac.id

Anonim. 2000. Hasil Pengkajian Sabut Kelapa sebagai Hasil Sampling, Bank Indonesia Jakarta. 15 hal.

Indahyani ,Titi (2011). Pemanfaatan Limbah Sabut Kelapa Pada Perencanaan Interior Dan Furniture Yang Berdampak Pada Pemberdayaan Masyarakat Miskin . Jurnal HUMANIORA Vol.2 No.1 April 2011

Opiyanti, M.R Yantu, Sisfahyuni. 2013. Analisis Nilai Tambah Serabut Kelapa Sebagai Bahan Baku Pembuatan Aneka Produk (Kasus Pt. Sumber Utama Lestari KecamatanTanantovea Kabupaten Donggala).J. Agroland 20 (2); 138-145. 
Putra, W.F.2011. Peluang Bisnis Industri Serat Serabut Kelapa. Yogyakarta: STMIK AMIKOM.

Rispul (2012). Kaligrafi Arab Sebagai Karya Seni . Jurnal Kajian Seni Budaya Islam Vol. 1, No. 1, Juni 2012

Shofiyah ,Maulia (2015). EKSPLORASI LIMBAH SABUT KELAPA ( Studi Kasus : Desa Handapherang Kecamatan Cijeunjing Kabupaten Ciamis ) . Jurnal e-Proceeding of Art \& Design : Vol.2, No.2 Agustus 2015

Sirojuddin (2014). Peta Perkembangan Kaligrafi Islam di Indonesia . Jurnal Al-Turāś Vol. XX No.1, Januari 2014

Suhardiyono, L., Tanaman Kelapa, Budidaya dan Pemanfaatannya, Hlm. 153156, Penerbit Kanisius, Yogyakarta, 1998.

Subarna, Abay D. dkk. 2006. Sistim Tulisan Dan Kaligrafi, LPSN, Jakarta. 